\title{
シアナミド処理がニホンナシ主要品種の自発休眠打破および開花期に及ぼす影響
}

\author{
黒木克翁 ${ }^{1} ・$ 竹村圭弘 ${ }^{4}$ ・松本和浩 ${ }^{2}$ ・武田 誠 ${ }^{3} ・$ 冨山政之 ${ }^{3}$ ・田村文男 ${ }^{4 *}$ \\ ${ }^{1}$ 鳥取大学大学院連合農学研究科 $680-8553$ 鳥取市湖山町 \\ 2 弘前大学農学生命科学部附属生物共生教育研究センタ一藤崎農場 038-3802 青森県南津軽郡藤崎町 \\ ${ }^{3}$ 日本カーバイド工業株式会社 108-8466 東京都港区港南 \\ 4 鳥取大学農学部 $680-8553$ 鳥取市湖山町
}

\section{Effect of Hydrogen Cyanamide on Breaking Flower Bud Endodormancy and Flowering Period of Major Japanese Pear Cultivars}

\author{
Katsuo Kuroki ${ }^{1}$, Yoshihiro Takemura ${ }^{4}$, Kazuhiro Matsumoto ${ }^{2}$, \\ Makoto Takeda ${ }^{3}$, Masanori Tomiyama ${ }^{3}$ and Fumio Tamura ${ }^{4 *}$ \\ ${ }^{I}$ The United Graduate School of Agricultural Science, Tottori University, Koyama-cho, Tottori 680-8553 \\ ${ }^{2}$ Fujisaki Farm, Teaching and Research Center for Bio-coexistence, Faculty of Agriculture and Life Science, Hirosaki University, Fujisaki-cho, \\ Minamitsugaru, Aomori 038-3802 \\ ${ }^{3}$ Nippon Carbide Industries Co., Inc., Konan, Minato-ku, Tokyo 108-8466 \\ ${ }^{4}$ Faculty of Agriculture, Tottori University, Koyama-cho, Tottori 680-8553
}

\begin{abstract}
In experiment 1, 'Kosui' and 'Gold Nijisseiki' pear cuttings that had accumulated various amounts of chilling were treated with 0.5 and $1.0 \%$ hydrogen cyanamide or 2.5 and $10.0 \%$ hydrogen peroxide. Although the effect of both regents on promoting budbreak depended on their concentration and chilling accumulation, hydrogen cyanamide was more effective than hydrogen peroxide in most chilling values. One point zero percent hydrogen cyanamide applied at Chill Unit (CU) 600 was the most effective for breaking bud dormancy among the treatments. In experiment 2, 0.5 and $1.0 \%$ hydrogen cyanamide were used to treat adult 'Kosui', 'Hosui', 'Gold Nijisseiki', and 'Niitaka' trees at CU300, 600, 900, and 1,500, and thereafter the percentage of budbreak, pollen development, and the flowering period were observed. The response of budbreak in flower buds to hydrogen cyanamide varies with chilling accumulation and the cultivar. The effective period for 'Kosui' and 'Gold Nijisseiki' was during CU300 to 900, that of 'Hosui' was CU600 to 900, and that of 'Niitaka' was CU900. Clear differences in the breaking of bud dormancy were observed among these hydrogen cyanamide treatments. However, pollen growth and flowering were over 2 days earlier than in the untreated control due to the treatment irrespective of broken/unbroken dormancy.
\end{abstract}

Key Words : chilling requirement, growth promotion, $\mathrm{H}_{2} \mathrm{CN}_{2}$, hydrogen peroxide

キーワード : $\mathrm{H}_{2} \mathrm{CN}_{2}$, 過酸化水素, 生育促進, 低温要求量

\section{緒言}

落葉果樹の芽の休眠打破に必要な低温要求量は，樹種あ るいは品種に固有のものであり, 低温要求量が満たされな い場合, 萌芽の遅延や不揃いが生じる（Saure, 1985; Westwood, 1978). このような低温の不足によって生じる自発休 眠打破不全を解決する手立てとしては，低温要求量の少な い品種を用いること，あるいは自発休眠打破剤の処理によ り低温の一部を補償する（黒井ら，1963）ことが必要とな る. ニホンナシ主要品種の休眠打破に必要な低温要求量は Tamura ら（2001）の報告により明らかとなって扣り，最も

2012 年 9 月 10 日 受付. 2013 年 1 月 10 日 受理.

* Corresponding author. E-mail: tamura@muses.tottori-u.ac.jp
少ない品種で Chill Unit（CU.）約 800 程度である.つまり， ニホンナシにおいてはリンゴ (Labuschagne ら，2002)，モ モ（Rodriguez ら，1994）など他の樹種にみられる CU. 300 〜 400 という極めて低温要求量の少ない品種は存在しない. 従って, 今後さらに進行する温暖化に対応するために, 特 に九州や西日本の二ホンナシ産地では，自発休眠打破剂の 効果的な使用技術の開発が望まれている.

果樹の自発休眠打破に有効な技術としては，石灰窒素の 上澄久液処理（黒井ら，1963; 森元・熊代，1978; ポジャナ ピモンら，2008; 田村ら，1993)，シアナミド処理 (Nir・Lavee, 1993; 大野・三井，2008; ポジャナピモンら，2008; Shulman ら，1983），ニンニクなどに含まれる硫化物処理（Kubota・ Miyamuki, 1992; ポジャナピモンら，2008），短時間の高温 処理（堀内・中川，1971; 田村ら，1993）, 捻よび過酸化水 
素溶液処理（Kuroda ら，2005）があげられている。ポジャ ナピモンら，(2008）は, シアナミド処理は他の剤と比較し て高い休眠打破効果を示したとして拈り，ニホンナシに対 しても同様に効果が期待される. しかし, シアナミドのニ ホンナシに対する休眠打破効果を検証した例は大野・三井 （2008）および田村（1999）の 2 例であり，いずれも明確な 技術確立には至っていない.さらに, ニホンナシの場合, シアナミド処理の効果は処理時期によって大きく異なる （田村, 1999）ことに加光, 前述の様に品種により低温要求 量が異なることから，品種ごとに適切な処理時期を明らか にする必要もある.

そこで本研究では, 現在の主要品種のらち, Tamura ら （2001）により低温要求量の少ないとされた品種 “幸水”之 “豊水”（CU. $800 〜 1,000 ）$ 扎よび，低温要求量が多いとさ れた品種 ‘ゴールド二十世紀’ と ‘新高’ (CU. 1,400 1,500）の計 4 品種を用い，休眠のステージごとにシアナミ ド溶液を浸漬法あるいは噴霧法で処理し自発休眠の推移， 花芽の成長および開花時期に及ぼす影響を調査した。

\section{材料および方法}

\section{1. シアナミドおよび過酸化水素水溶液の浸漬処理が二ホ ンナシの腋花芽の自発休眠打破に及ぼす影響（実験 1）}

実験には, 鳥取大学農学部附属大塚農場に栽植されてい る ‘幸水’（33 年生）および ‘ゴールド二十世紀’（12 年 生）それぞれ 5 樹より採取した 1 年生発育枝を用いた。採 取は $2007 〜 2008$ 年の休眠期に行った.

発育枝は，12月 20 日 (CU. 600)，1月 5 日 (CU. 900)， 1 月 15 日 (CU. 1,200) 扎よび 1 月 28 日（CU. 1,500）に固 場より採取し, 腋花芽が連続して 8 節着生するように調整 後，シアナミド（CX-10，日本カーバイド工業） $0.5 \%$ あ いは $1.0 \%$ 水溶液, 過酸化水素 $2.5 \%$ あるいは $10 \%$ 水溶液に 2 秒間浸漬した. 処理後の枝は，腐敗防止のため $0.03 \%$ 硫 酸アルミニウムおよび $0.3 \%$ 8- ヒドロキシキノリンを添加 した水溶液中に打いた吸水性スポンジに水挿し, 腋花芽の 萌芽率を調査した。 また，水插した発育枝は， $23 \pm 0.5^{\circ} \mathrm{C}$, 相対湿度 $75 \%$, 照度 $6,0001 x ， 16$ 時間日長に制御した恒温 室内で育成し, 水扦し後 28 日目の萌芽率を調査した. 調査 中，発育枝基部が黒変したものについては，正常な部分ま で切り戻しを行い, その都度, 水溶液および吸水性スポン ジは新しいものに取り換えた.

本実験では，腋花芽のりん片が緩んだ後，明瞭な緑色を 呈した状態を萌芽と定義し，萌芽率の算出を行った，萌芽 率は各発育枝の上位 5 節の萌芽の有無から求め, 5 本の平 均值で示した。

Chill Unit は, 実験圃場内に設置した百葉箱内に置いた自 動記録温度計により計測したデータを用い, Tamura ら （1997）の Chill Unit モデルを用いて算出した.
2. シアナミドの散布時期および濃度の違いがニホンナシ の自発休眠打破，花芽の発育および開花日に及ぼす影 響（実験 2)

実験は, 鳥取大学農学部附属大塚農場に栽植されている “幸水’（34 年生），“豊水’（34 年生）、“ゴールド二十世紀” （13 年生）打よび ‘新高’（34 年生）をそれぞれ 8 樹ずつ用 いた. $2008 〜 2009$ 年にかけての休眠期に処理時期抒よび 処理濃度を变化させたシアナミド散布処理を行った。

処理日は, 12 月 2 日 (CU. 300), 12 月 20 日 (CU. 600), 1 月 4 日（CU. 900）物よび 1 月 30 日（CU. 1,500）の計 4 日で，シアナミド $0.5 \%$ 抢よび $1.0 \%$ 水溶液を樹全体に対し て噴霧器を用い $150 \mathrm{~mL} \cdot \mathrm{m}^{-2}$ 程度散布した.

\section{1）自発休眠打破に関する調查}

シアナミド処理が萌芽率に及ぼす影響を調査するため に, 処理直後以降定期的に発育枝を採取し実験 1 と同様の 方法で萌芽率を調査した.

\section{2）花芽の発育，開花期に関する調査}

調査には，3 月 $6 \sim 20$ 日にかけて経時的に短果枝を各処 理区 3 芽採取し，直ちに FAA 液（70\%エタノール：酶酸： ホルマリン $=90: 5: 5, \mathrm{v} / \mathrm{v} / \mathrm{v})$ で固定した．花芽の発達状態 を花粉の成熟度から評価するために親花の 4 番花 (混合芽の 中の花芽で花序軸の下位から 4 番目の小花）の原基を取出 し, 水洗後, 葯をスライドガラス上に滴下した少量の蒸留水 中に置いた.これをピンセットで軽く揉みほぐし花粉を取り 出した．その後，直ちにカバーガラスをかけ，顕微鏡下で無 作為に抽出した 3 視野, 各 100 粒の花粉の発育状態を観察 し，80\%以上の花粉が四分子期に達した日を記録した.

開花日の調查は國場に括いて目視で行った。親花の 1 お よび 2 番花の開花をもって「開花」とし，同一処理区の側 枝上の短果枝のうち $80 \%$ 以上が開花に達した日を「開花日」 とした。

\section{結 果}

\section{1. シアナミドおよび過酸化水素水溶液の浸漬処理がニホ} ンナシの腋花芽の自発休眠打破に及ぼす影響（実験 1）

シアナミド処理区の萌芽率は，CU. 600 扤よびCU. 1,500 での処理で，無処理区よりも高い値を示し（第 1 図），特

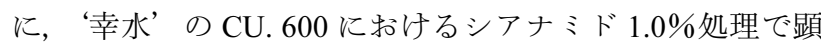
著であった. しかし, 無処理区の発芽が全く認められなかっ たCU. 900 でのシアナミド処理において萌芽はほとんど促 進されなかった。一方, 過酸化水素処理区の萌芽率は, ‘幸 水'の CU. 1,500 飞打汀る過酸化水素 $2.5 \%$ 処理区で無処理 区よりも高い值を示したが，それ以外の処理区では無処理 区との間に差は認められなかった。

2. シアナミドの散布時期および濃度の違いがニホンナシ の自発休眠打破，花芽の発育および開花日に及ぼす影 響（実験 2)

1）自発休眠打破に関する調査

各処理時期における萌芽率の推移は, 品種間で異なった。 

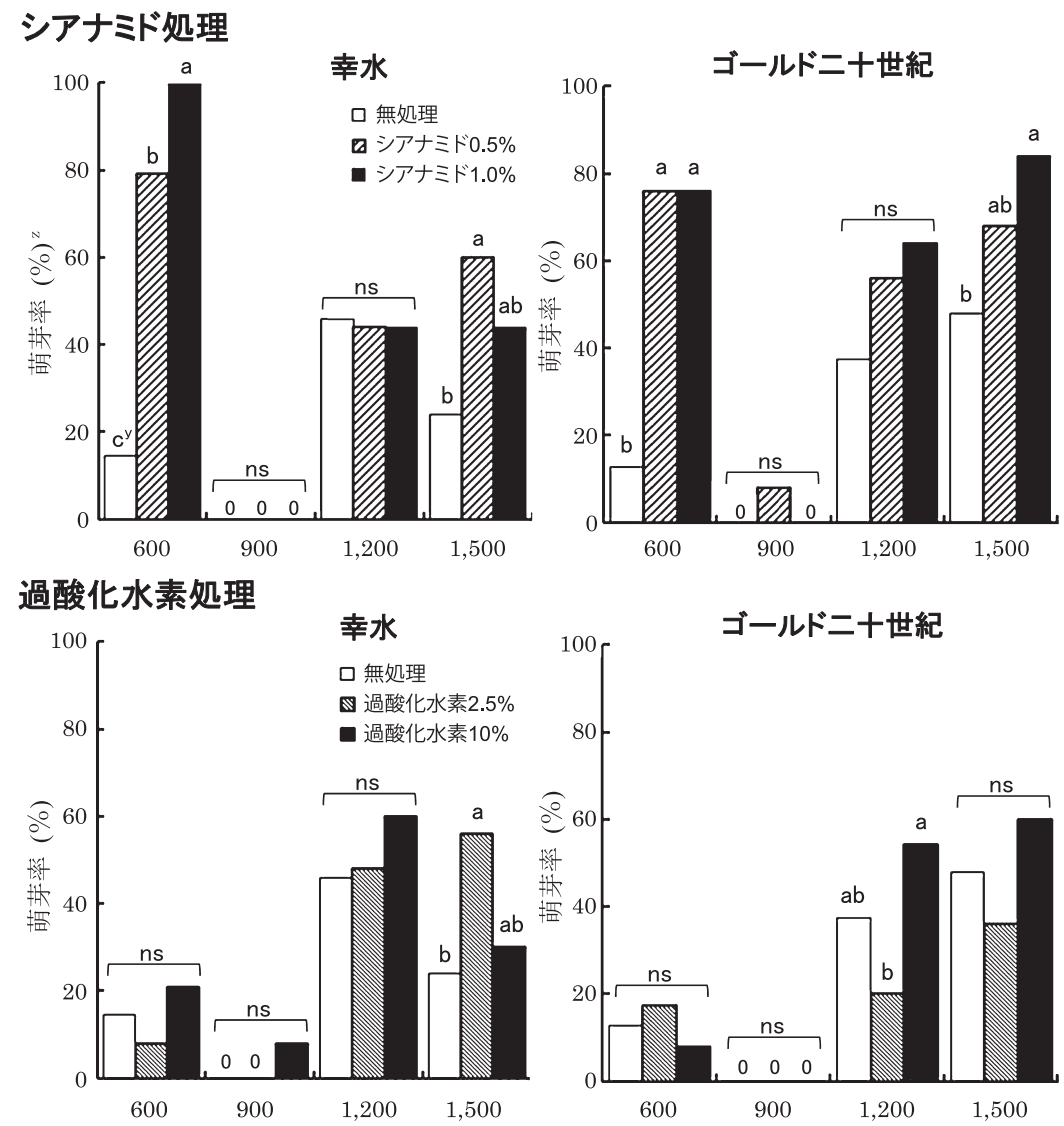

Chill Unit (処理時) ${ }^{x}$

第1図 シアナミドならびに過酸化水素浸漬処理が‘ゴールド二十世紀”扣よび‘幸水’の腋花芽の休眠打破に及洔寸影響 ${ }^{\mathrm{z}} 23^{\circ} \mathrm{C}$ で水插し加温処理後 28 日目飞調査

y 同一処理日に执いて異なる英文字は $\chi^{2}$ 検定において $5 \%$ 水準で有意差があることを示す, ns : 有意差なし $(n=5)$

x 11 月 15 日を起算日とした

“幸水’ の無処理区の萌芽率は，CU. 600 および CU. 900 で 低く推移し CU. 1,200 では 60\%以上を示した（第 1 表）。一 方, シアナミド処理区の処理直後の萌芽率は, CU. 1,500を 除いて全処理時期ともシアナミド $0.5 \%$ と比べ $1.0 \%$ 処理区 が高かった。 また，CU. 300 におけるシアナミド処理区の 萌芽率は処理後高い值を示し, CU. 600 には一時的に低下 するものの CU. 900 には無処理区よりも高い值を示した. また，CU. 600 およびCU. 900 における処理に打いても無 処理区と比べ高く, 特にシアナミド $1.0 \%$ 処理区で顕著で あった. また，その後 CU. 1,500 に打ける処理では無処理 区の萌芽率が高くなり，漂とんどの処理区で差はみられな かった.

“豊水”の無処理区の萌芽率は, すべて $70 \%$ 以上の值で 推移した. 同様に, 処理直後の萌芽率は, 無処理区と同程 度であった. しかし，“幸水’同様 CU. 300 時のシアナミド 1.0\%処理区では，CU. 600 に一度萌芽率が減少した.

‘ゴールド二十世紀” の無処理区の萌芽率は，CU. 300 で は70\%と高いものの, CU. 600 では減少し, さらにCU. 900 には $0 \%$ となり，その後CU. 1,500には $88 \%$ となった。 シ
アナミド処理区の萌芽率は“幸水”同様，CU. 600 抢よび CU. 900 における処理で高く，無処理区と差異を示し，特 に $1.0 \%$ 処理で顕著であった。 それ以降 CU. 1,500 における 萌芽率は無処理区と処理区間で差はなかった。また，CU． 300 におけるシアナミド処理では $0.5 \%$ 処理区の萌芽率が無 処理区と比べ低かった。 これと同様に，1.0\%処理区では CU. 600 に扣いて萌芽率が著しく低下するもののCU.900に は高くなるといら ‘幸水”, “豊水” と類似した推移を示し た。 ‘新高’ の無処理区の萌芽率は，CU. 300, CU. 600, CU. 900 打よびCU. 1,200 で低く推移し CU. 1,500 では 100\%と なった。 これに対し，シアナミド処理区の萌芽率は，“ゴー ルド二十世紀” と同様に CU. 900 時の処理に抢いて無処理 区と比べ高い值を示した，その後，CU. 1,500に拈ける萌芽 率に差はなかったが CU. 300 およびCU. 600 に処理を行っ た区では無処理区よりも低い傾向にあった。

\section{2）花芽の発育，開花期に関する調査}

2009年に抢ける無処理区の花粉の四分子期到達日は，“幸 水’，“豊水’および ‘ゴールド二十世紀’では 3 月 16 日， “新高”では 3 月 12 日であった（第 2 表）。一方，シアナミ 
第 1 表 シアナミド処理が ‘幸水’，“豊水’，“ゴールド二十世紀’ および ‘新高’の腋花芽の自発休眠の推移に及ぼす影響

\begin{tabular}{|c|c|c|c|c|c|c|c|}
\hline \multirow{3}{*}{ 品種 } & \multirow{3}{*}{$\begin{array}{l}\text { Chill Unit } \\
\text { (処理時) }\end{array}$} & \multirow{3}{*}{ 処理濃度（\%) } & \multicolumn{5}{|c|}{ Chill Unit（水挿し加温開始日） } \\
\hline & & & 300 & 600 & 900 & 1,200 & 1,500 \\
\hline & & & \multicolumn{5}{|c|}{ 萌芽率（\%） $\mathrm{x}$} \\
\hline \multirow{9}{*}{ 幸水 } & \multicolumn{2}{|c|}{ 無処理 } & $50 \mathrm{~b}^{\mathrm{y}}$ & $0 \mathrm{c}$ & $12 \mathrm{c}$ & $64 \mathrm{bc}$ & $100 \mathrm{a}$ \\
\hline & \multirow{2}{*}{300} & 0.5 & $36 \mathrm{~b}$ & $33 \mathrm{~b}$ & $70 \mathrm{ab}$ & $32 \mathrm{c}$ & $100 \mathrm{a}$ \\
\hline & & 1.0 & $91 \mathrm{a}$ & $41 \mathrm{~b}$ & $86 \mathrm{a}$ & $100 \mathrm{a}$ & $100 \mathrm{a}$ \\
\hline & \multirow{2}{*}{600} & 0.5 & - & $30 \mathrm{~b}$ & $36 \mathrm{c}$ & $29 \mathrm{c}$ & $76 \mathrm{bc}$ \\
\hline & & 1.0 & - & $90 \mathrm{a}$ & $47 \mathrm{~b}$ & $86 \mathrm{ab}$ & $95 \mathrm{ab}$ \\
\hline & \multirow{2}{*}{900} & 0.5 & - & - & $38 \mathrm{c}$ & $100 \mathrm{a}$ & $78 \mathrm{bc}$ \\
\hline & & 1.0 & - & - & $88 \mathrm{a}$ & $91 \mathrm{a}$ & $95 \mathrm{ab}$ \\
\hline & \multirow{2}{*}{1,500} & 0.5 & - & - & - & - & $69 \mathrm{c}$ \\
\hline & & 1.0 & - & - & - & - & $86 \mathrm{abc}$ \\
\hline \multirow{9}{*}{ 豊水 } & \multicolumn{2}{|c|}{ 無処理 } & $78 a b$ & $71 \mathrm{a}$ & $100 \mathrm{a}$ & $95 \mathrm{a}$ & $100 \mathrm{a}$ \\
\hline & \multirow{2}{*}{300} & 0.5 & $64 \mathrm{~b}$ & $56 \mathrm{ab}$ & $78 \mathrm{~b}$ & $71 \mathrm{~b}$ & $90 \mathrm{a}$ \\
\hline & & 1.0 & $100 \mathrm{a}$ & $28 \mathrm{~b}$ & $73 \mathrm{~b}$ & $65 \mathrm{~b}$ & $100 \mathrm{a}$ \\
\hline & \multirow{2}{*}{600} & 0.5 & - & $63 \mathrm{a}$ & $86 \mathrm{ab}$ & $91 \mathrm{ab}$ & $100 \mathrm{a}$ \\
\hline & & 1.0 & - & $75 \mathrm{a}$ & $72 \mathrm{~b}$ & $100 \mathrm{a}$ & $100 \mathrm{a}$ \\
\hline & \multirow{2}{*}{900} & 0.5 & - & - & $100 \mathrm{a}$ & $100 \mathrm{a}$ & $100 \mathrm{a}$ \\
\hline & & 1.0 & - & - & $100 \mathrm{a}$ & $100 \mathrm{a}$ & $100 \mathrm{a}$ \\
\hline & \multirow{2}{*}{1,500} & 0.5 & - & - & - & - & $100 \mathrm{a}$ \\
\hline & & 1.0 & - & - & - & - & $86 \mathrm{a}$ \\
\hline \multirow{9}{*}{$\begin{array}{l}\text { ゴールド } \\
\text { 二十世紀 }\end{array}$} & \multicolumn{2}{|c|}{ 無処理 } & $70 \mathrm{a}$ & $40 \mathrm{bc}$ & $0 \mathrm{c}$ & $33 \mathrm{c}$ & $88 \mathrm{a}$ \\
\hline & \multirow{2}{*}{300} & 0.5 & $4 \mathrm{~b}$ & $13 \mathrm{c}$ & $72 \mathrm{~b}$ & $96 \mathrm{ab}$ & $100 \mathrm{a}$ \\
\hline & & 1.0 & $88 \mathrm{a}$ & $29 \mathrm{c}$ & $72 b$ & $100 \mathrm{a}$ & $100 \mathrm{a}$ \\
\hline & \multirow{2}{*}{600} & 0.5 & - & $63 \mathrm{ab}$ & $76 \mathrm{~b}$ & $81 \mathrm{~b}$ & $80 \mathrm{~b}$ \\
\hline & & 1.0 & - & $76 \mathrm{a}$ & $92 \mathrm{a}$ & $77 \mathrm{~b}$ & $100 \mathrm{a}$ \\
\hline & \multirow{2}{*}{900} & 0.5 & - & - & $96 \mathrm{a}$ & $96 a b$ & $96 \mathrm{a}$ \\
\hline & & 1.0 & - & - & $100 \mathrm{a}$ & $92 \mathrm{ab}$ & $100 \mathrm{a}$ \\
\hline & \multirow{2}{*}{1,500} & 0.5 & - & - & - & - & $32 \mathrm{c}$ \\
\hline & & 1.0 & - & - & - & - & $63 \mathrm{~b}$ \\
\hline \multirow{9}{*}{ 新高 } & \multicolumn{2}{|c|}{ 無処理 } & $0 \mathrm{~b}$ & $25 \mathrm{ab}$ & $0 \mathrm{~d}$ & $20 \mathrm{c}$ & $100 \mathrm{a}$ \\
\hline & 300 & 0.5 & $12 \mathrm{ab}$ & $4 \mathrm{~b}$ & $16 \mathrm{c}$ & $44 \mathrm{bc}$ & $50 \mathrm{c}$ \\
\hline & 300 & 1.0 & $32 \mathrm{a}$ & $25 \mathrm{ab}$ & $38 \mathrm{bc}$ & $55 \mathrm{~b}$ & $70 \mathrm{bc}$ \\
\hline & 600 & 0.5 & - & $35 \mathrm{a}$ & $55 \mathrm{ab}$ & $42 \mathrm{bc}$ & $79 \mathrm{bc}$ \\
\hline & 000 & 1.0 & - & $39 a$ & $25 \mathrm{c}$ & $41 \mathrm{bc}$ & $87 \mathrm{ab}$ \\
\hline & 900 & 0.5 & - & - & $48 \mathrm{ab}$ & $88 \mathrm{a}$ & $88 \mathrm{ab}$ \\
\hline & 900 & 1.0 & - & - & $75 \mathrm{a}$ & $87 \mathrm{a}$ & $75 \mathrm{bc}$ \\
\hline & 1,500 & 0.5 & - & - & - & - & $71 \mathrm{bc}$ \\
\hline & 1,500 & 1.0 & - & - & - & - & $68 \mathrm{bc}$ \\
\hline
\end{tabular}

${ }^{\mathrm{z}} 11$ 月 15 日を起算日とし, CU. 300 (12 月 2 日), CU. 600 (12 月 20 日)，CU. 900 （1 月 4 日）抽よ゙ CU. 1,500（1月 30 日）に 0.5 \%または $1.0 \%$ シアナミド処理を行った

$\mathrm{y}$ 同一の品種に拈ける同列内の異なる英文字は $\chi^{2}$ 検定に拈いて $5 \%$ 水準で有意差があることを示す

${ }^{\mathrm{x}} 23^{\circ} \mathrm{C}$ で水挿し加温処理後 28 日目に調査

ド処理区では四分子期到達日は最大で ‘幸水’で 6 日，“豊 水’では 10 日, ‘ゴールド二十世紀’では 6 日, ‘新高’で は 6 日早まった。

2009 年に扔ける無処理区の開花日は“豊水’および‘新
高’が 4 月 12 日，“ゴールド二十世紀’では 4 月 14 日，“幸 水’では 4 月 16 日であった (第 3 表)。これに対し，いず れの品種とも, すべてのシアナミド処理区の開花日は, そ れ卆れ無処理区より早くなった。 ‘新高’のシアナミド処理 
第 2 表 シアナミド処理が ‘幸水”, ‘豊水’, ‘ゴールド二十世 紀’および ‘新高’の花粉の四分子期到達日に及ぼす影響

\begin{tabular}{|c|c|c|c|c|c|}
\hline \multirow{2}{*}{$\begin{array}{c}\text { 処理日 z } \\
\text { (Chill Unit) }\end{array}$} & \multirow{2}{*}{$\begin{array}{c}\text { 処理 } \\
\text { 濃度 } \\
(\%)\end{array}$} & \multicolumn{4}{|c|}{ 四分子期到達日 ${ }^{x}$ （月／日） } \\
\hline & & 幸水 & 豊水 & $\begin{array}{l}\text { ゴールド } \\
\text { 二十世紀 }\end{array}$ & 新高 \\
\hline 無処理 & & $3 / 16$ & $3 / 16$ & $3 / 16$ & $3 / 12$ \\
\hline 300 & $\begin{array}{l}0.5 \\
1.0\end{array}$ & $\begin{array}{l}3 / 10(-6)^{y} \\
3 / 14(-2)\end{array}$ & $\begin{array}{ll}3 / 14 & (-2) \\
3 / 14 & (-2)\end{array}$ & $\begin{array}{ll}3 / 14 & (-2) \\
3 / 10 & (-6)\end{array}$ & $\begin{array}{ll}3 / 6 & (-6) \\
3 / 10 & (-2)\end{array}$ \\
\hline 600 & $\begin{array}{l}0.5 \\
1.0\end{array}$ & $\begin{array}{ll}3 / 14 & (-2) \\
3 / 14 & (-2)\end{array}$ & $\begin{array}{lr}3 / 10 & (-6) \\
3 / 6 & (-10)\end{array}$ & $\begin{array}{ll}3 / 14 & (-2) \\
3 / 14 & (-2)\end{array}$ & $\begin{array}{ll}3 / 10 & (-2) \\
3 / 6 & (-6)\end{array}$ \\
\hline 900 & $\begin{array}{l}0.5 \\
1.0\end{array}$ & $\begin{array}{ll}3 / 14 & (-2) \\
3 / 14 & (-2)\end{array}$ & $\begin{array}{ll}3 / 14 & (-2) \\
3 / 14 & (-2)\end{array}$ & $\begin{array}{ll}3 / 14 & (-2) \\
3 / 10 & (-6)\end{array}$ & $\begin{array}{ll}3 / 12 & (0) \\
3 / 10 & (-2)\end{array}$ \\
\hline 1,500 & $\begin{array}{l}0.5 \\
1.0\end{array}$ & $\begin{array}{ll}3 / 14 & (-2) \\
3 / 10 & (-6)\end{array}$ & $\begin{array}{ll}3 / 10 & (-6) \\
3 / 10 & (-6)\end{array}$ & $\begin{array}{ll}3 / 14 & (-2) \\
3 / 14 & (-2)\end{array}$ & $\begin{array}{rr}3 / 10 & (-2) \\
3 / 12 & (0)\end{array}$ \\
\hline
\end{tabular}

${ }^{\mathrm{z}}$ Chill Unit モデル（Tamura ら，1997）を使用

$\mathrm{y}$ 括弧内は無処理区と比べ四分子期到達日が前進した日数

${ }^{\mathrm{x}} 80 \%$ の花粉が四分子期に達した日 $(\mathrm{n}=9)$

第 3 表 シアナミド処理が ‘幸水’, “豊水’, ‘ゴールド二十世 紀’および ‘新高’の開花日に及ぼす影響

\begin{tabular}{|c|c|c|c|c|c|c|}
\hline \multirow{2}{*}{$\begin{array}{c}\text { 処理日 }^{z} \\
\text { (Chill Unit) }\end{array}$} & \multirow{2}{*}{$\begin{array}{c}\text { 処理 } \\
\text { 濃度 } \\
(\%)\end{array}$} & \multicolumn{5}{|c|}{ 開花日 ${ }^{x}$ (月 /日) } \\
\hline & & 幸水 & 豊 & 水 & $\begin{array}{l}\text { ゴールド } \\
\text { 二十世紀 }\end{array}$ & 新高 \\
\hline 無処理 & & $4 / 16$ & $4 /$ & 12 & $4 / 14$ & $4 / 12$ \\
\hline 300 & $\begin{array}{l}0.5 \\
1.0\end{array}$ & $\begin{array}{ll}4 / 13 & (-3)^{y} \\
4 / 13 & (-3)\end{array}$ & $\begin{array}{l}4 / 9 \\
4 / 7\end{array}$ & $\begin{array}{l}(-3) \\
(-5)\end{array}$ & $\begin{array}{ll}4 / 10 & (-4) \\
4 / 9 & (-5)\end{array}$ & $\begin{array}{ll}4 / 9 & (-3) \\
4 / 9 & (-3)\end{array}$ \\
\hline 600 & $\begin{array}{l}0.5 \\
1.0\end{array}$ & $\begin{array}{ll}4 / 11 & (-5) \\
4 / 10 & (-6)\end{array}$ & $\begin{array}{l}4 / 6 \\
4 / 5\end{array}$ & $\begin{array}{l}(-6) \\
(-7)\end{array}$ & $\begin{array}{ll}4 / 10 & (-4) \\
4 / 10 & (-4)\end{array}$ & $\begin{array}{ll}4 / 9 & (-3) \\
4 / 7 & (-5)\end{array}$ \\
\hline 900 & $\begin{array}{l}0.5 \\
1.0\end{array}$ & $\begin{array}{ll}4 / 12 & (-4) \\
4 / 12 & (-4)\end{array}$ & $\begin{array}{l}4 / 10 \\
4 / 9\end{array}$ & $\begin{array}{l}(-2) \\
(-3)\end{array}$ & $\begin{array}{ll}4 / 10 & (-4) \\
4 / 10 & (-4)\end{array}$ & $\begin{array}{ll}4 / 9 & (-3) \\
4 / 8 & (-4)\end{array}$ \\
\hline 1,500 & $\begin{array}{l}0.5 \\
1.0\end{array}$ & $\begin{array}{ll}4 / 12 & (-4) \\
4 / 13 & (-3)\end{array}$ & $\begin{array}{l}4 / 8 \\
4 / 9\end{array}$ & $\begin{array}{l}(-4) \\
(-3)\end{array}$ & $\begin{array}{ll}4 / 13 & (-1) \\
4 / 10 & (-4)\end{array}$ & $\begin{array}{ll}4 / 9 & (-3) \\
4 / 8 & (-4)\end{array}$ \\
\hline
\end{tabular}

${ }^{\mathrm{z}}$ Chill Unit モデル（Tamura ら，1997）を使用

${ }^{\mathrm{y}}$ 括弧内は無処理区と比べ開花日が前進した日数

x 開花率が $80 \%$ に達した日

区の中ではCU. 600 時に行った $1.0 \%$ 処理区の開花が最も早 く, 無処理区ょり 5 日早い 4 月 7 日であった.さらに, “豊 水’でも CU. 600 時に行ったシアナミド $1.0 \%$ 処理区の開花 が最も早く, 無処理区より 7 日早い 4 月 5 日であった。 ‘幸 水”でも同様に, CU. 600 時に行ったシアナミド $1.0 \%$ 処理 区の開花が最も早くなり, ‘ゴールド二十世紀’では CU. 300 時に行ったシアナミド $1.0 \%$ 処理区の開花が最も早く なった。

\section{考察}

温暖な地域では, 落葉果樹の芽の自発休眠打破に必要な 低温が不足するため，シアナミドのような人工的に休眠を 打破させる薬剤などの処理が必要である. 本研究は, 二ホ ンナシ主要品種の自発休眠打破技術の開発のための知見を
得るため, 他の樹種において有効であるシアナミド処理を 行い, 芽の自発休眠打破ならびに春季の芽の生育に及ぼす 影響について明らかにしょらとしたものである。まず，シ アナミド処理と過酸化水素処理の効果の比較を行った結 果, シアナミド処理が過酸化水素処理より萌芽を促進させ ることを明らかにした（第1図）。しかし，田村（1999）が 示したよらに, シアナミド処理の効果は処理時期によって 大きく異なった。“幸水”扎よび ‘ゴールド二十世紀”は CU. 600 時におけるシアナミド $1.0 \%$ 浸漬処理が最も効果的 であった。しかし，対照区の萌芽率が最も低いCU. 900 で の浸漬処理では, 効果がみられなかった. 以上のことより, 浸漬処理区に打いては，CU. 600 に処理をすることで高い 自発休眠打破効果を得られることが明らかといえる.

次に, 本研究では, シアナミド処理後の萌芽率の推移を 調査したが，その推移は，品種間で異なった，無処理区の CU. 300 の萌芽率は, “新高”以外の 3 品種で高い值を示し, 品種間で異なることから，導入に有効な温度に品種間差異 があるものと予測された，また，“幸水”は “二十世紀” に 比べ自発休眠への導入が早いことが示されて和り（Tamura ら，2001）これらの差異が品種間の反応の違いに関連して いるのかもしれない.

その後, 自発休眠は, ‘幸水”の次に低温要求量の多い “ゴールド二十世紀”拈よび ‘新高”の順で破れ Tamura ら （2001）の報告と一致した（第 1 表）。しかし，理由は不明 であるが ‘豊水’の無処理区の萌芽率は，調査期間中 $70 \%$ 以上で推移し，自発休眠導入を確認することができなかっ た. Tamura ら（2001）は, ‘豊水’の葉芽は他の品種と比較 して自発休眠期中にも20～30\% と高い萌芽率を示すことを 認めている.さらに，腋花芽は葉芽よりも休眠が浅い（田 村ら，1995）ことから，“豊水’の腋花芽の休眠の深さを本 研究で行った水扦法で評価することは困難と思われた.

“幸水”および ‘ゴールド二十世紀’ の CU. 900 時の萌芽 率は, CU. 300, CU. 600 時に処理した区で高く，これらの 時期でのシアナミド処理が自発休眠打破を促進させた。 ま た, CU. 900 でのシアナミド処理も萌芽を促進し, 特に 1.0 $\%$ 区で高い萌芽率を示した。一方，4品種の中で最も低温 要求量の多い ‘新高’（Tamura ら，2001）の萌芽率は, ‘幸 水”および ‘ゴールド二十世紀”の 2 品種に拈いて処理効 果のあったCU. 300, CU. 600 時では, 無処理区と大きな差 はなかった. CU. 900 での処理では無処理区よりも有意に 高い萌芽率を示し, 他の品種同様シアナミド 1.0\%処理で顕 著であった。 その後, CU. 1,500 に打ける萌芽率をみると, CU. 300, CU. 600 およびCU. 1,500 に処理を行った区では, いずれも無処理区よりも低い傾向にあった．その原因はシ アナミド処理による薬害であるかは明確ではないが，これ までに， 巨峰’（黒井，1985）でシアナミドによる薬害が 報告されているため, この点に関しては今後検討する必要 がある，次に，“幸水”および ‘ゴールド二十世紀”の CU. 900 における処理では, 浸漬処理および噴霧処理で結果が 
異なった，その理由については不明であるが，実際に露地 でのシアナミド処理を想定して行った噴霧処理で高い自発 休眠打破効果が得られた. 従って, シアナミド処理は低温 要求量の最も少ない“豊水”ではCU. $600 \sim 900$ に扔いて, 低温要求量の多い ‘新高’ では CU. 900 亿打いて高い自発 休眠打破効果を有するといえる. また，“幸水”および ‘ゴー ルド二十世紀’ は, 実験 1 打よび実験 2 の CU. 900 での処 理で結果が異なったため，CU. 900 より CU. 600 に処理を 行らことで安定的に自発休眠を打破でき, 処理を行ららえ で有効な時期であると考兄られた。

本研究では, CU. 300 といった早い時期にシアナミド処 理を行うと, 処理直後の萌芽率は高まるが, その後, 低温 が蓄積され CU. 600 程度になると, 萌芽率が一旦低下し, さらに CU. 900 以降になると再度無処理区以上の萌芽率を 示すといった興味深い結果が得られた。 この現象, 寸なわ ち CU. 600 での萌芽率の低下は, 竹村ら（2011）が示した ように，ニホンナシの芽の休眠は低温により導入されるた め，この間の低温により再び休眠が深まったからではない かと推察される。 また，処理濃度に注目寸ると，4品種と も今回処理した $1.0 \%$ と $0.5 \%$ では, $1.0 \%$ 処理の効果が高 かった.

次に以上の処理区の春季に抢ける生育についてみると, 休眠打破効果に打いては品種ごとに有効な処理時に差異が あったものの, すべてのシアナミド処理区で生育促進がみ られた. すなわち，シアナミド処理区の花粉の四分子期到 達日は，湾ぼすべての区で 2 日以上早まった（第 2 表）。ま た，開花に関しては“幸水”ではすべての処理区に扒いて 無処理区よりも $3 \sim 6$ 日, “豊水”では $3 \sim 7$ 日, ‘ゴール ド二十世紀’ では 4 5 日, “新高’では $3 \sim 5$ 日開花が促 進された (第 3 表)。このような全品種共通した春期の花器 の発達促進は, 低温条件でも高い呼吸速度を維持するシア ン耐性呼吸鎖（Cole ら，1982）を発達させるからではない かと推測された.

以上のように，春季の生育を促進するうえでは CU. 600 に達した時点で $1.0 \%$ 程度のシアナミドを処理する方法が 最も効果的であるといえた。

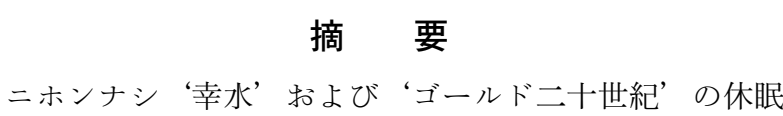
期の枝に 0.5 抽よび $1.0 \%$ シアナミドならびに 2.5 拈よび 10.0 \%過酸化水素水溶液を浸漬処理し, 腋花芽の萌芽に及洔す 影響を調べた。萌芽の促進に対する両処理の影響は，それ ぞれの濃度和よび処理時期に依存したが, シアナミドが過 酸化水素よりも萌芽を促進した。特に, Chill Unit（CU.) 600 での $1.0 \%$ シアナミド処理が, 全処理区内で最も休眠打 破効果が高かった．次に，シアナミドの処理時期抢よび濃 度の違いが自発休眠打破ならびに春季の発育に及活す影響 を調査するために ‘幸水”, “豊水”，“ゴールド二十世紀” 拈よび ‘新高’の成木に CU. 300, CU. 600, CU. 900 およ
びCU. 1,500 時に 0.5 および $1.0 \%$ シアナミドを処理し，そ の後の萌芽率，花粉発育および開花期を観察した．腋花芽 に打ける休眠打破の反応は, 品種ごとに異なり, “幸水”打 よび ‘ゴールド二十世紀’では CU. 600，“豊水’では CU. $600 \sim 900$, ‘新高’ では CU. 900 に行った処理が効果的で あった．また，処理濃度は $1.0 \%$ が効果的であることが明ら かとなった，一方，いずれの時期拈よび濃度であってもシ アナミド処理を行った樹体の花粉発育，萌芽および開花は 無処理区より早くなった.

\section{引用文献}

Cole, M. E., T. Solomos and M. Faust. 1982. Growth and respiration of dormant flower buds of Pyrus communis and Pyrus calleryana. J. Amer. Soc. Hort. Sci. 107: 226-231.

堀内昭作・中川昌一. 1971. 果樹の休眠に関する研究. (第 2 報）休眠打破について（ブドウ）．園学要旨．昭 46 春: $132-133$.

Kubota, N. and M. Miyamuki. 1992. Breaking bud dormancy in grapevines with garlic paste. J. Amer. Soc. Hort. Sci. 117: 898-901.

Kuroda, H., T. Sugiura and H. Sugiura. 2005. Effect of hydrogen peroxide on breaking endodormancy in flower buds of Japanese pear (Pyrus pyrifolia Nakai). J. Japan. Soc. Hort. Sci. 74: 255-257.

黒井伊作. 1985. カルシウム・シアナミド及びシアナミド がブドゥ ‘巨峰’の芽の休眠打破に及活す影響. 園学 雑. 54: 301-306.

黒井伊作・白石義行・今野 茂. 1963. ブドウの休眠打破 飞関する研究 (第一報)。ガラス室栽培樹の自発休眠短 縮に及洔寸石灰窒素処理の効果. 園学雑. 32: 176-180.

Labuschagne, I. F., J. H. Louw, Karin Schmidt and Annalene Sadie. 2002. Genetic variation in chilling requirement in apple progeny. J. Amer. Soc. Hort. Sci. 127: 663-672.

森元福雄・熊代克己. 1978. 薬剤処理による落葉果樹の休 眠打破に関する研究. 信州大農紀要. 15: 1-17.

Nir, G. and S. Lavee. 1993. Metabolic changes during cyanamide induced dormancy release in grapevines. Acta Hortic. 329: 271-274.

大野秀一・三井友宏. 2008 . シアナミド液剂処理が露地栽 培ニホンナシ ‘幸水’の開花に及ぼす影響. 園学研. 7 (別 1): 296.

ポジャナピモン チャイワット・福田文夫・久保田尚浩. 2008. 四倍体ブドゥ 7 品種の芽の休眠打破に及ぼす低 温遭遇量と化学物質の影響. 園学研. 7: 261-268.

Rodriguez, J., W. B. Sherman, R. Scorza, M. Wisniewski and W. R. Okie. 1994. 'Evergreen' peach, its inheritance and dormant behavior. J. Amer. Soc. Hort. Sci. 119: 789-792.

Saure, M. C. 1985. Dormancy release in deciduous fruit trees. Hort. Rev. 7: 239-300. 
Shulman, Y., G. Nil, L. Fanberstein and S. Lavee. 1983. The effect of cyanamide on release from dormancy of grape vine buds. Sci. Hortic. 19: 97-104.

竹村圭弘・須藤幸子・池田隆政・松本和浩・田村文男. 2011. ニホンナシ ‘ゴールド二十世紀’ の芽の自発休眠は低 温によって誘導される. 園学研. 10: 87-92.

田村文男. 1999. 落葉果樹の芽の休眠. 植物の化学調節. 34: 264-272.

田村文男・田辺賢二・伴野 潔・池田隆政. 1993. ニホン ナシ ‘二十世紀” の芽の休眠打破に及ぼす高温処理の 影響. 園学雑. 62: 41-47.
田村文男・田辺賢二・板井章浩. 1995. ニホンナシ数品種 の芽の自発休眠の特徵. 園学雑. 64（別 1）：162-163. Tamura, F., K. Tanabe and A. Itai. 1997. A model for estimating rest completion for 'Nijisseiki' pear. Environ. Control Biol. 35: $185-189$.

Tamura, F., K. Tanabe, A. Itai and M. Morimoto. 2001. Variations in the chilling requirements for breaking leaf bud endodormancy in wild pear species and pear cultivars. J. Japan. Soc. Hort. Sci. 70: 596-598.

Westwood, M. N. 1978. Temperate-Zone Pomology. p. 199-303. W. H. Freeman and Company, New York. 